\title{
Selective bacterial separation of critical metals: a sustainable method for recycling lithium ion batteries
}

\author{
Virginia Echavarri-Bravo ${ }^{\mathrm{a}, \mathrm{e}}$, Houari Amari ${ }^{\dagger \mathrm{b}, \mathrm{e}}$, Jennifer Hartley, ${ }^{\mathrm{c}, \mathrm{e}}$, Giovanni Maddalena $^{\mathrm{a}, \mathrm{e}}$, Caroline Kirk ${ }^{\mathrm{d}}$, Maarten W. Tuijtel ${ }^{\ddagger a}$, \\ Nigel. D. Browning ${ }^{b, e, f, g}$, Louise E. Horsfall ${ }^{* a, e}$ \\ The large scale recycling of lithium ion batteries (LIBs) is essential to satisfy global demands for the raw materials required to implement this technology as \\ part of a clean energy strategy. However, despite what is rapidly becoming a critical need, an efficient and sustainable recycling process for LIBs has yet to be \\ developed. Biological reactions occur with great selectivity under mild conditions, offering new avenues for the implementation of more environmentally \\ sustainable processes. Here, we demonstrate a sequential process employing two bacterial species to recover $\mathrm{Mn}$, Co and $\mathrm{Ni}$, from vehicular LIBs through the \\ biosynthesis of metallic nanoparticles, whilst Li remains within the leachate. We investigated bio-selectivity between Co and Ni using proteomics, confirming \\ control of the biological response. Our approach determines the principles and first steps of a practical bio-separation and recovery system, underlining the \\ relevance of harnessing biological specificity for recycling and up-cycling critical materials
}

\section{Introduction}

It is well established that one of the most important measures to slow climate change is a reduction in $\mathrm{CO}_{2}$ emissions. Road transportation is highly dependent on carbon-based fuels and responsible for $20 \%$ of $\mathrm{CO}_{2}$ emissions worldwide. ${ }^{1}$ Therefore, there is mounting pressure to move towards transportation alternatives with lower carbon footprints, leading to many national governments incentivising the transition to electric vehicles (EV) for mobility. These pressures and incentives are resulting in an increasing demand for lithium ion batteries (LIBs), ${ }^{2}$ currently the best technological solution to power EV based on energy density. ${ }^{3}$ Life cycle assessment of LIBs shows that the availability of raw materials needed to fulfil the demand for EV LIBs by 2050 is estimated to be 'very critical' for both lithium and cobalt, and 'critical' for others such as copper and nickel. 4,5 Thus, the development of efficient technologies to enable selective recovery and recycling of the components and materials present in spent LIBs is vital to minimising risks in the supply chain and reducing waste burden. ${ }^{6}$ Moreover, moving to a circular economy for LIBs would reduce reliance on the current sources of raw materials associated with human rights abuses and decrease mining activities reported to negatively impact upon human and environmental health. ${ }^{7}$

Current recycling methods are multi-step processes, often starting with physical separation of the various battery parts, or shredding and comminution, followed by a combination of other physical, hydrometallurgical and/or pyrometallurgical processes. $3,6,7$ Hydrometallurgical methods involve the dissolution of battery parts, often using sulfuric acid or hydroxides, ${ }^{8}$ with other secondary treatments (e.g. thermal, sonication) that result in the production of

School of Biological Sciences, University of Edinburgh, Edinburgh, EH9 3BF, UK. Department of Mechanical, Materials and Aerospace Engineering, University of Liverpool, Liverpool, L69 3GQ, UK.

School of Chemistry, University of Leicester, Leicester, LE1 7RH, UK.

d. School of Chemistry, University of Edinburgh, Edinburgh, EH9 3FJ, UK

Faraday Institution (ReLiB project), Quad One, Harwell Science and Innovation Campus, Didcot, UK

f. Sivananthan Laboratories, 590 Territorial Drive, Bolingbrook, IL 60440, USA g. Physical and Computational Sciences Directorate, Pacific Northwest National Laboratory, P.O. Box 999, Richland, WA 99352, USA

${ }^{+}$Present address: Leibniz Institute for Crystal Growth, Max-Born-Str. 2, 12489 Berlin, Germany.

¥Present address: Department of Structural Biology, Max Planck Institute of Biophysics, Max-von-Laue Strasse 3, 60438 Frankfurt am Main, Germany;

*Corresponding author. Email: Louise.Horsfall@ed.ac.uk

Electronic Supplementary Information (ESI) available. Proteomics data can be accessed at https://doi.org/10.7488/ds/3130 battery leachates with varying concentrations of metals dependent on the chemistry of the cathode. The downstream separation of metals contained in the battery leachates is generally achieved by solvent-exchange, however the energy inputs and the use of hazardous chemicals are major limiting factors for achieving a cost effective and sustainable process., ${ }^{3,7}$ The development of greener methods that enable the selective separation of metals from battery leachates and allows for their return to use is a major challenge for the industry. ${ }^{3}$ Here the incorporation of biological methods into the process (Fig. 1) may provide the key, as bioprocessing occurs at relatively low temperatures $\left(<37^{\circ} \mathrm{C}\right)$ and does not involve the use of hazardous compounds. ${ }^{9}$

In this study, we used bacteria for metal bio-recycling, as they grow quickly and are engineered more easily in comparison to other microorganisms, should the process require such optimisation. We examined the selective separation and recovery of the most relevant metals ( $\mathrm{Co}, \mathrm{Li}, \mathrm{Mn}$ and $\mathrm{Ni}$ ) present in EV LIB leachates prepared with strong mineral acids using two bacterial species, Shewanella oneidensis MR-1 and Desulfovibrio alaskensis G20. These bacteria reportedly precipitate dissolved $\mathrm{Mn}$ and $\mathrm{Ni}$ ions in the form of $\mathrm{Mn}$

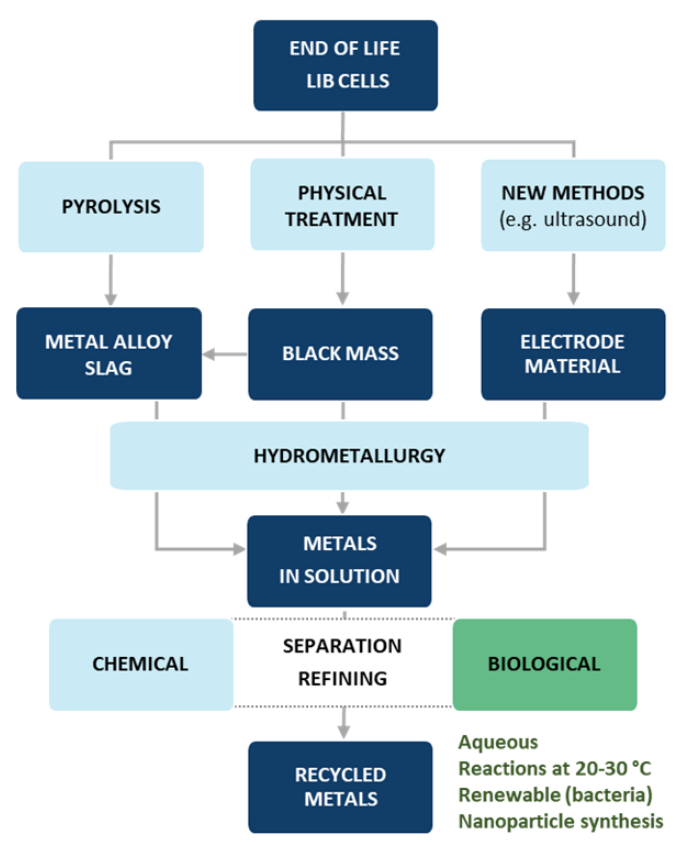

Fig. 1. Recycling diagram depicting main conventional recycling processes (light blue) for end of life LIB cells and resulting fractions containing metals (dark blue), and our biological separation process (green) to support the development of more sustainable solutions. 
oxide $^{10}$ and $\mathrm{Ni}$ sulfide nanoparticles (NPs) ${ }^{11}$ respectively. The biological mechanisms responsible for metal removal such as biosorption, bioprecipitation and bioreduction are ubiquitous but, in the main, are metal and bacterial species-specific. Metal oxidoreduction reactions resulting in nanoparticle synthesis are usually associated with the production of metal reducing and metal binding compounds such as enzymes and non-enzymatic proteins. ${ }^{9}$ During the course of this work we confirmed the synthesis of Co NPs by $D$. alaskensis $\mathrm{G} 20$. Thus we interrogated the proteome of $D$. alaskensis G20 to gain insight into the biological pathways responsible for the precipitation of $\mathrm{Co}$ and $\mathrm{Ni}$. It is crucial to recycle both metals as they are currently essential in the majority of EV LIB chemistries; Co is a critical element and there is an increasing demand for $\mathrm{Ni}$ due the rapid adoption of high-Ni cathodes. ${ }^{12,13}$

\section{Results and discussion}

\section{LIB-relevant metal bioremoval}

Our studies began by ascertaining the efficiency of $\mathrm{Mn}$ bioprecipitation by $S$. oneidensis MR-1. Experiments using singlemetal solutions showed the removal of $\mathrm{Mn}$ from the dissolved fraction increased with increasing initial $\mathrm{Mn}^{2+}$ concentration, 360 ppm being the highest mass removal from an initial concentration of 1000 ppm (Fig. 2a). The highest removal efficiency was $83 \%$ of dissolved $\mathrm{Mn}^{2+}$ at 100 ppm (Fig. 2b), although not all $\mathrm{Mn}$ removal can be associated to bacterial activity as $\mathrm{Mn}^{2+}$ precipitated in the abiotic control ( $27 \%$ at 100 ppm incubation concentration). Nevertheless, taking incubation times and cell densities into account, the removal rate obtained in this study is encouraging compared to previous work with Shewanella putrefaciens that required longer incubation times, up to 10 days, to achieve $80 \%$ removal at an incubation concentration of $125 \mathrm{ppm} .{ }^{14}$ Analysis by X-ray powder diffraction (XRPD) identified the white precipitate obtained at the end of the
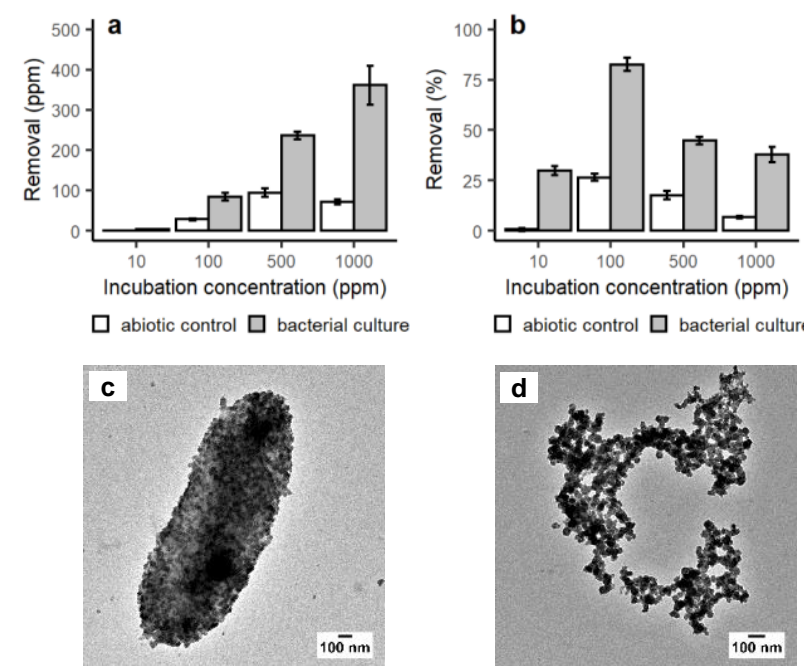

Fig. 2 Removal of dissolved $\mathrm{Mn}^{2+}$ expressed as Mean $\pm \mathrm{SD}(\mathrm{n}=3)$ measured as (a) ppm and (b) percent with cell cultures of $S$. oneidensis MR-1 and abiotic control. TEM images of nanoparticles produced by $S$. oneidensis MR-1 incubated with $1000 \mathrm{ppm}$ of $\mathrm{Mn}^{2+}$ (c) coating the bacterial cells and (d) detached from bacterial biomass. incubation period as $\mathrm{MnCO}_{3}$ (ESI, Fig.S1). Transmission electron microscopy (TEM) imaging confirmed that this biogenic $\mathrm{MnCO}_{3}$ was in the form of nanoparticles coating the bacterial cells (Fig. 2c) and was also detached from cell biomass (Fig. 2d). With the latter material having the greater potential for re-use in LIB electrodes. ${ }^{15}$ With a similar batch process approach we demonstrated that $D$. alaskensis $\mathrm{G} 20$ was able to remove both $\mathrm{CO}^{2+}$ and $\mathrm{Ni}^{2+}$ from the dissolved fraction with an efficiency above $70 \%$ at $10 \mathrm{ppm}$. The net mass recovery of $\mathrm{Ni}$ varied little across the different incubation concentrations (Fig. 3a) meaning the removal efficiency decreased with increasing $\mathrm{Ni}$ concentration (Fig. 3b). Whereas the removal (ppm) of Co was significantly higher at the incubation concentration of $50 \mathrm{ppm} \mathrm{Co}{ }^{2+}($ Mean $\pm \mathrm{SD}=11.9 \pm 1.5)$ than it was at $10 \mathrm{ppm} \mathrm{Co}^{2+}$ (Mean $\pm S D=6.8 \pm 0.8$ ) (t-test, $p=0.006$ ) but the efficiency within a $20 \mathrm{~h}$ batch process was better at the lower concentration. As vehicular LIBs leachates may contain both metals, the removal of Co and $\mathrm{Ni}$ when in mixed solution was also studied. The bimetallic experiments showed that overall the presence of $\mathrm{Ni}^{2+}$ significantly decreased the removal of $\mathrm{Co}^{2+}$ at all three incubation concentrations tested (Fig. 3a). The pairwise comparison of Co removal between the single and the bimetallic treatments showed statistically significant differences at $50 \mathrm{ppm}$ incubation concentration (t-test, $p<0.001$ ). The differing removal profiles of these metals underpins the existence of different biological mechanisms responsible for $\mathrm{Co}^{2+}$ and $\mathrm{Ni}^{2+}$ precipitation. This provides opportunities for process optimisation through genetic engineering rather than solely through more traditional engineering means.

Acting in addition to the biological mechanisms is the formation of cobalt and nickel sulfides due to the presence of biogenic hydrogen sulfide $\left(\left[\mathrm{H}_{2} \mathrm{~S}\right]<160 \mu \mathrm{mol} \mathrm{L}^{-1}\right.$ ) (ESI, Fig. S2). Whilst the cells were thoroughly washed and resuspended in nutrient-free buffer prior to the beginning of the removal experiments, biogenic sulfide could have been produced during the maintenance of the bacterial cell steady-state. ${ }^{16}$ Metal removal by $\mathrm{H}_{2} \mathrm{~S}$ is relatively efficient and in the bacterial cell-free supernatant was above $70 \%$ due to the presence of dissolved $\mathrm{H}_{2} \mathrm{~S}\left(24.5 \mathrm{mmol} \mathrm{L}^{-1}\right)$, however it exhibits no specific selectivity for Co or Ni (ESI, Fig. S3). ${ }^{17} \mathrm{Co}$ and Ni precipitation was not detected by ICP-OES in fresh nutrient media or 3-(N-morpholino) propanesulfonic acid (MOPS) buffer abiotic controls.

Upon examination of the bacterial cells post-treatment using cryo$E M$, we observed areas of high-density in the bacterial envelope of cells incubated with $50 \mathrm{ppm} \mathrm{Co}{ }^{2+}$ (Fig. 4b) compared to cells in the
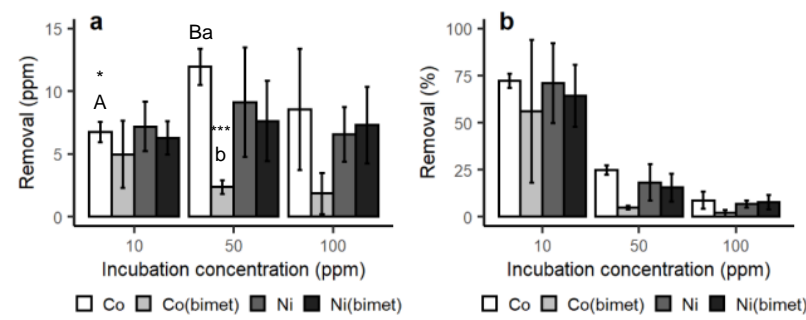

Fig. 3 Removal of $\mathrm{CO}^{2+}$ and $\mathrm{Ni}^{2+}$ expressed as Mean $\pm \mathrm{SD}(\mathrm{n}=3)$ measured as (a) ppm and (b) percent with $D$. alaskensis $\mathrm{G} 20$. Columns with different capital letters indicate significant difference between 10 and $50 \mathrm{ppm}$ of $\mathrm{Co}^{2+}$ (two-sided t-test $\mathrm{p}<0.05\left({ }^{*}\right)$ ) and lower case letters show differences at $50 \mathrm{ppm}$ of $\mathrm{Co}^{2+}$ in absence/presence of $\mathrm{Ni}$ ( two-sided t-test $\mathrm{p}<0.001(* * *))$. 

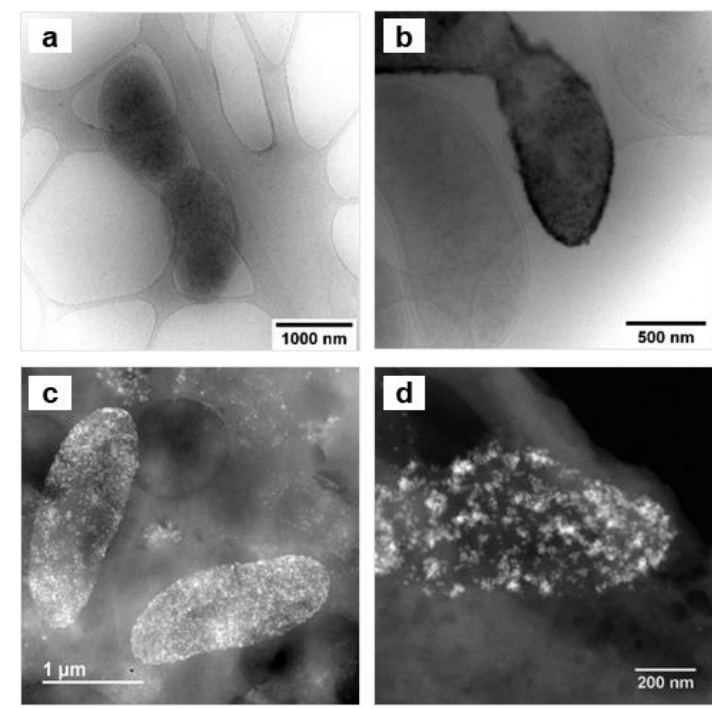

Fig. 4 Cryo-EM images of $D$. alaskensis $\mathrm{G} 20$ (a) in the control treatment and (b) after incubation with $50 \mathrm{ppm}$ of $\mathrm{Co}^{2+}$. STEM image of samples of $D$. alaskensis $\mathrm{G} 20$ incubated for $20 \mathrm{~h}$ at $10 \mathrm{ppm}$ of $\left(\right.$ c) $\mathrm{Co}^{2+}$ (d) $\mathrm{Ni}^{2+}$.

control treatment (Fig. 4a). STEM imaging also showed the presence of high-density areas covering the surface of bacterial cells incubated with $\mathrm{Co}^{2+}$ (Fig. 4c) and $\mathrm{Ni}^{2+}$ (Fig. 4d) at $10 \mathrm{ppm}$, depicting the formation of metallic nanoparticles.

Selective bioprecipitation of dissolved $\mathrm{Mn}$ from vehicular LIBs leachates To investigate metal removal/precipitation from vehicular battery leachates we dissolved cathode material with two different mineral acids, $\mathrm{H}_{2} \mathrm{SO}_{4}$ or $\mathrm{HCl}$, both widely used in hydrometallurgy. ${ }^{18}$ The concentration of metals ( $\mathrm{Al}, \mathrm{Co}, \mathrm{Mn}$, $\mathrm{Li}$ and $\mathrm{Ni}$ ) in these LIB leachates was dependent upon the origin of the cathode material, solvent used and thermal treatment (ESI, Table S1). Prolonged incubation times, from 5 to 30 minutes in $0.1 \mathrm{M} \mathrm{H}_{2} \mathrm{SO}_{4}$ doubled the leaching of $\mathrm{Co}, \mathrm{Li}$ and $\mathrm{Mn}$, and increased $\mathrm{Al}$ and $\mathrm{Ni}$ concentrations even further. The final dissolved metal composition of the leachates was very different according to the battery type/cathode chemistry and the acid used, $\mathrm{H}_{2} \mathrm{SO}_{4}$ or $\mathrm{HCl}$. Two cathode materials A1C (Nickel Manganese and Cobalt, ratio 50\% nickel, 30\% manganese, and 20\% cobalt (NM -352)) and B1C (Lithium Manganese oxide spinel (LMO) with $25 \%$ Lithium Nickel Cobalt aluminium Oxide (NCA) ${ }^{19}$ ) were used in the present work. Comparable leaching data for $\mathrm{H}_{2} \mathrm{SO}_{4}$ and $\mathrm{HCl}$ at $20^{\circ} \mathrm{C}$ is available in ESI Fig. S4.

The specificity for dissolved $\mathrm{Mn}$ and the removal rates achieved by $S$. oneidensis MR-1 with vehicular leachates were in agreement with the results we obtained in the previous experiments using metal salts. The capability exhibited by this bacterium for the selective precipitation of $\mathrm{Mn}^{2+}$ out of the mixed metals contained in the crude leachates is extremely relevant for establishing the principles of a bio-separation process (Fig.5, ESI Table S2). The removal efficiency of $\mathrm{Mn}$ peaked at $75 \%$ (154 ppm) from leachates of the cathode material $\mathrm{B} 1 \mathrm{C}$ dissolved in $0.1 \mathrm{M} \mathrm{H}_{2} \mathrm{SO}_{4}$ for 30 minutes at $50{ }^{\circ} \mathrm{C}$ (Fig. 5iv). The removal of the other metals was low, generally well below $5 \%$ total precipitated mass, except for Co when present at concentrations above 70 ppm (Fig. 5ii) and Al contained in $\mathrm{HCl}$ leachates (Fig. 5v-vi) Fortunately, a recent advance using selective hydrometallurgical

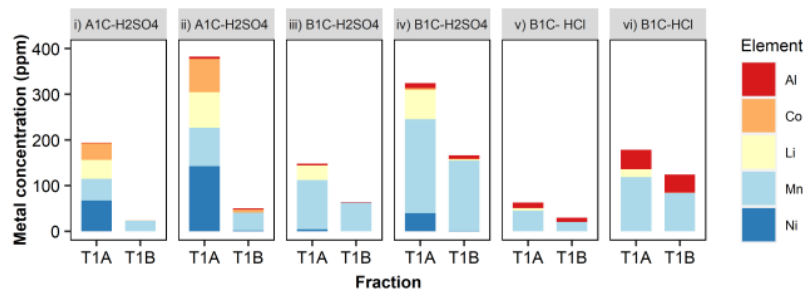

Fig. 5 Bioprecipitation of metals contained in vehicular LIBs using $S$. oneidensis MR-1. Selected leachates: cathode $\mathrm{A} 1 \mathrm{C}$ at $50{ }^{\circ} \mathrm{C}$ in $0.1 \mathrm{M} \mathrm{H}_{2} \mathrm{SO}_{4}$ for (i) $5 \mathrm{~min}$ and (ii) $30 \mathrm{~min}$; cathode $\mathrm{B} 1 \mathrm{C}$ at $50{ }^{\circ} \mathrm{C}$ in $0.1 \mathrm{M} \mathrm{H}_{2} \mathrm{SO}_{4}$ for (iii) 5 min and (ii) $30 \mathrm{~min}$; (iv) cathode $\mathrm{B} 1 \mathrm{C}$ at $20^{\circ} \mathrm{C}$ in $0.1 \mathrm{M} \mathrm{HCl}$ for (v) $5 \mathrm{~min}$ and (vi) $300 \mathrm{~min}$. Metal concentration in the raw leachate (T1A) and metal removal/precipitated (T1B) expressed as the Mean ( $n=3$ biological replicates)

methods combined with high-intensity ultrasonication can now be employed to provide leachates with a lower concentration of Al. ${ }^{20}$

\section{Two bacterial treatment bio-processing approach}

In order to develop a complete and selective bio-recycling process, we chose to combine the ability of $D$. alaskensis $\mathrm{G} 20$ to precipitate $\mathrm{Ni}$ and/or Co from a leachate that had been previously processed (pretreated) with S. oneidensis MR-1 (see diagram depicted in Fig. 6). To enable the use of more acidic leachates, prepared with $0.5 \mathrm{M}$ $\mathrm{H}_{2} \mathrm{SO}_{4}$, we added carbonate-bicarbonate buffer to $\mathrm{S}$. oneidensis MR1 cell culture. Small-scale $(2 \mathrm{ml})$ experiments confirmed this buffer would aid the biological removal of $\mathrm{Mn}$ from leachates prepared in $0.5 \mathrm{M} \mathrm{H}_{2} \mathrm{SO}_{4}$ (ESI, Fig. S5). The results obtained were very encouraging with the B1C leachate (Fig. 7ai T1B, ESI Table S3) as the precipitation of $\mathrm{Mn}$ was enhanced to $89 \%$ and the dissolved $\mathrm{Mn}$ present in the downstream fraction (T1C) was reduced to just 10 ppm. A higher (97\%) Mn removal was achieved from the $\mathrm{A} 1 \mathrm{C}$ leachate, however the precipitated Mn exhibited lower purity (63\% total precipitated metal mass) due to co-precipitation of Al (4\%), Co (22\%) and $\mathrm{Ni}$ (10\%) (Fig. 7bi T1B, ESI Table S4).

After $\mathrm{Mn}$ removal using $S$. oneidensis $\mathrm{MR}-1$, we processed the fractions containing the remaining dissolved metals (T1C) for both $\mathrm{B} 1 \mathrm{C}$ and $\mathrm{A} 1 \mathrm{C}$ leachates with $\mathrm{D}$. alaskensis $\mathrm{G} 20$ to precipitate $\mathrm{Ni}$ and $\mathrm{Co}$. The initial concentration of dissolved $\mathrm{Co}$ and $\mathrm{Ni}$ (fraction T2A) was lower in the B1C leachate (Fig. 7aii-iv, ESI Table S3) than in the A1C (Fig. 7bii-iv, ESI Table S4) due to the differences between the cathode chemistries. The removal of $\mathrm{Co}$ and Ni when working with the whole

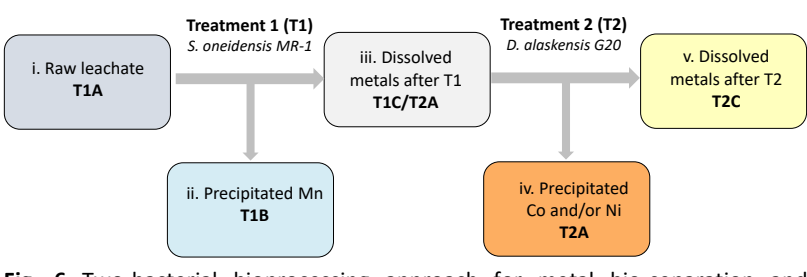

Fig. 6 Two-bacterial bioprocessing approach for metal bio-separation and recycling. Diagram depicting the two bacterial treatment processes and the resulting fractions: dissolved metals contained in the raw leachate (T1A), precipitated metals (T1B) after treatment $1(\mathrm{~T} 1)$ with $S$. oneidensis MR-1 and remaining metals in dissolved fraction after T1 (T1C). T2A represents the initial concentration of dissolved metals (different volumes of $\mathrm{T} 1 \mathrm{C}$ ) before treatment 2 (T2) with $D$. alaskensis $\mathrm{G} 20$. T2B corresponds to the precipitated metals and $\mathrm{T} 2 \mathrm{C}$ to metals remaining in the dissolved fraction after $\mathrm{T} 2$. 

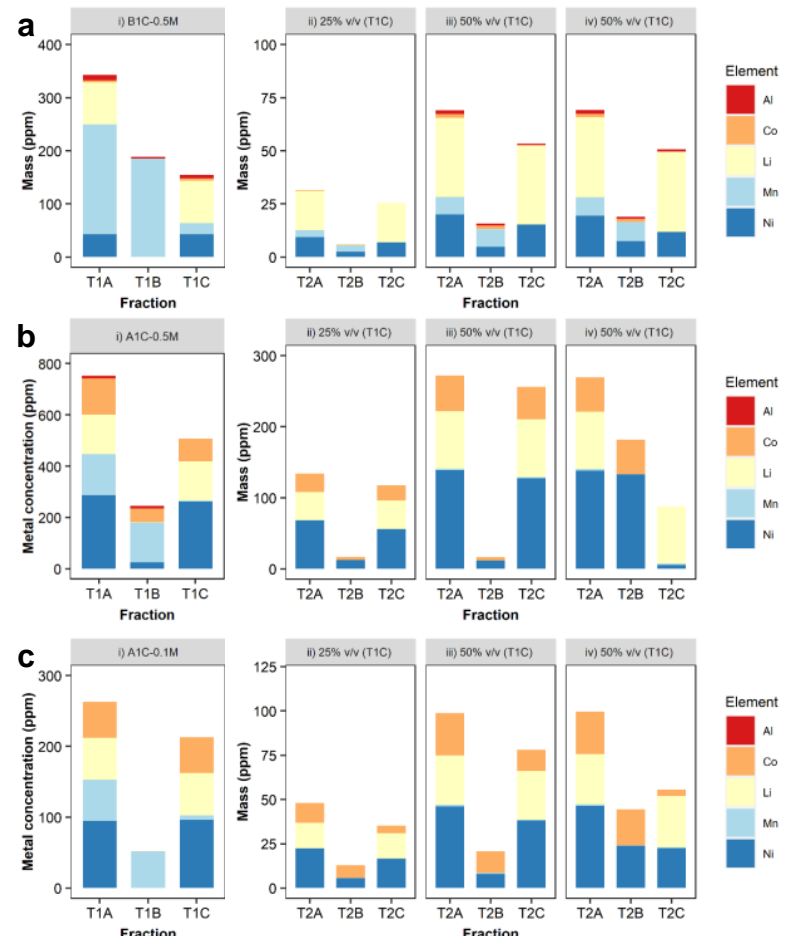

Fig. 7 Bio-separation of metals contained in leachates prepared with (a) $\mathrm{B} 1 \mathrm{C} 0.5$ $\mathrm{M} \mathrm{H}_{2} \mathrm{SO}_{4}$ (b) A1C $0.5 \mathrm{M}$ (c) A1C $0.1 \mathrm{M} \mathrm{H}_{2} \mathrm{SO}_{4}$. Metal concentration expressed as the Mean ( $n=3$ biological replicates) associated to different stages of (i) T1 and $\mathrm{T} 2$ (ii-iii) cell-only treatment and (iv) whole cell culture.

bacterial culture was larger than with the cell-only treatment possibly due to the higher concentration of $\mathrm{H}_{2} \mathrm{~S}$ enhanced metal precipitation as $\mathrm{Ni}$ and Co sulfides. Since our aim was to establish a bio-process that enabled a bio-separation of Co from $\mathrm{Ni}$, the results obtained with the cell-only treatment were more relevant as these demonstrated that by adjusting the concentrations and ratios between $\mathrm{Co}$ and $\mathrm{Ni}$ we can modulate the metal specificity of $D$. alaskensis $\mathrm{G} 20$. We observed higher selectivity for the removal of $\mathrm{Ni}$ when this metal was present at concentrations above $50 \mathrm{ppm}$ (conditions with $\mathrm{A} 1 \mathrm{C} 0.5 \mathrm{M} \mathrm{H}_{2} \mathrm{SO}_{4}$ leachate, $\mathrm{Ni}$ and $\mathrm{Co}$ were in the ratio $8: 3$ ) in agreement with the results obtained during the bimetallic experiments at $50-100 \mathrm{ppm}$. The release of extracellular proteins with high $\mathrm{Ni}$-affinity as a mechanism of bacterial stress response caused by this metal may explain differences between Co and $\mathrm{Ni}$ removals. ${ }^{21}$ Since $\mathrm{Ni}$ was present at toxic concentrations for D. alaskensis $\mathrm{G} 20$ in the $\mathrm{A} 1 \mathrm{C} 0.5 \mathrm{M} \mathrm{H}_{2} \mathrm{SO}_{4}$ leachate, we investigated the removal of $\mathrm{Ni}$ and $\mathrm{Co}$ from a leachate (A1C, $0.1 \mathrm{M} \mathrm{H}_{2} \mathrm{SO}_{4}$ ) containing lower concentrations of both metals, in the ratio 2:1 This time $D$. alaskensis $\mathrm{G} 20$ showed preference for precipitating $\mathrm{Co}$, and by increasing the volume of leachate from 25 to $50 \% \mathrm{v} / \mathrm{v}$, the removal increased by $70 \%$ for $\mathrm{Co}, 12.2 \mathrm{ppm}$, and $40 \%$ for $\mathrm{Ni}, 7.9 \mathrm{ppm}$ (Fig. 7c, ESI Table S5).

Proteomic analysis of the bacterial response to $\mathrm{Ni}$ and $\mathrm{Co}$ In order to develop our understanding of a biological separation process we investigated the biological molecules and mechanisms responsible for $\mathrm{Co}$ and $\mathrm{Ni}$ nanoparticle synthesis. The proteins produced by $D$. alaskensis $\mathrm{G} 20$ after incubation with $\mathrm{Co}^{2+}$ and/or $\mathrm{Ni}^{2+}$ were analysed by Electrospray lonisation Mass Spectrometry (ESI)-HPLC-MS/MS. 1579 proteins were identified in this study which corresponds to $52 \%$ a
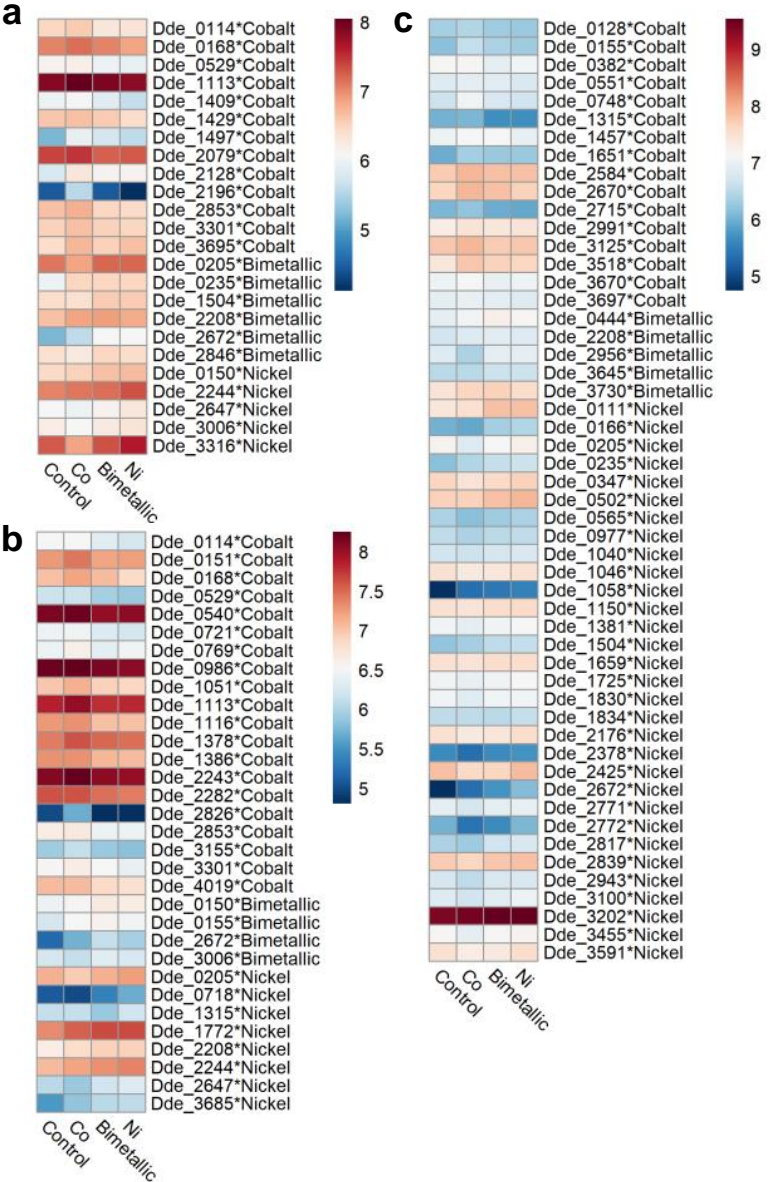

Fig. 8 Proteomics analysis. Heat maps of protein abundance associated to the control and metal treatments ( $\mathrm{Co}, \mathrm{Ni}$ and bimetallic) after $2 \mathrm{~h}$ incubation with metals at (a) $10 \mathrm{ppm}$ and (b) $100 \mathrm{ppm}$ and (c) after $20 \mathrm{~h}$ incubation with metals at $10 \mathrm{ppm}$. Values are represented as the log 10 (Mean protein abundance, $n=3$ biological replicates). Rows are labelled with the protein identifier Dde_\#\#\#\# followed by the *metal treatment exhibiting the highest significant abundance (ANOVA, $p$-value $<0.05$, number of peptides detected $\geq 2$, absolute ratio abundance $>1.5$-fold). The protein abundance, ANOVA results and full name of the proteins together with their associated ID is available at https://doi.org/10.7488/ds/3130.

of the total proteome of $D$. alaskensis $\mathrm{G} 20,22$ providing comprehensive coverage of the bacterial response to the presence of these two transition metals, relative to previous studies. ${ }^{21,23}$ Overall, higher similarities were found between the control and Co treatments compared to $\mathrm{Ni}$-containing treatments, according to the specific protein abundance profiling especially after $2 \mathrm{~h}$ metal incubation (ANOVA, $p$-value $<0.05$, peptide number $\geq 2$, absolute ratio abundance $>1.5$ ). After $2 \mathrm{~h}$ incubation there was a remarkable reduction in the protein abundance in treatments containing 100 ppm of $\mathrm{Ni}^{2+}$ in comparison to the control. It is also particularly noteworthy that metal-binding proteins, such as the UPF0173 metaldependent hydrolase (Dde_0151), the quinone-interacting membrane-bound oxidoreductase (Dde_1113) and the MJ0042 family finger-like protein (Dde_1116), showed the highest abundance in the presence of $100 \mathrm{ppm} \mathrm{Co}{ }^{2+}$ and yet the lowest abundance for the 100 ppm bimetallic treatment (Fig. 8b). UPF0173 metal-dependent hydrolases and $\mathrm{MJ0042}$ family finger-like proteins are known for binding $\mathrm{Zn}^{2+}$ that can be exchanged by $\mathrm{Co}^{2+}$ without a loss of functionality. ${ }^{24,25}$ To reduce the risk of mis-metallation with $\mathrm{Ni}$, or perhaps to remedy such, it is understandable that a decrease 
in their abundance is observed and this might then also explain why Co removal from the dissolved fraction dropped when $\mathrm{Ni}^{2+}$ was present at concentrations $\geq 50 \mathrm{ppm}$.

After $20 \mathrm{~h}$ incubation, 23 proteins showed higher abundance in the treatment with $\mathrm{Ni}^{2+}$ compared to the Control and $\mathrm{Co}^{2+}$ treatments (Fig. 8c). Some of these proteins are likely responsible for mediating $\mathrm{Ni}^{2+}$ toxicity, such as the zinc resistance-associated protein (Dde_0111) which belongs to a family of four-helix hooked hairpins. ${ }^{26}$ Also proteins that might be involved in metal reduction processes such as oxidoreductases, ${ }^{27,28}$ were significantly more abundant after $20 \mathrm{~h}$ incubation with $10 \mathrm{ppm}$ of $\mathrm{Ni}^{2+}$ compared to the treatment with $\mathrm{Co}^{2+}$, confirming a distinctive cellular response depending on the metal. Some of these oxidoreductases, such as the FAD/NAD (P)-binding domain protein (Dde_1381) and the FADdependent pyridine nucleotide-disulfide oxidoreductase (Dde_2176), classified within the xenobiotics biodegradation and metabolism pathways, might be responsible for reducing $\mathrm{Ni}^{2+}$ into a less toxic form of this metal.

We identified similar cellular responses to $\mathrm{Co}^{2+}$, and $\mathrm{Ni}^{2+}$, with regard to $A B C$ transporters as the periplasmic component of zinc $A B C$ transporter protein (Dde_2208) and the Molybdenum $A B C$ transporter (Dde_0155), were both more abundant in the presence of any metal treatment compared to the control. Dde_0155 had been identified in previous work with $D$. alaskensis $\mathrm{G} 20$ after incubation with $\mathrm{Pd}^{2+}$ and $\mathrm{Pt}^{4+} 29$ suggesting that this protein is a key component of heavy metal detoxification pathways. ${ }^{30}$ Conversely, other proteins related to the $A B C$ transporter pathways were found at significantly larger concentrations after incubation with $\mathrm{Co}^{2+}$ alone than after treatments containing $\mathrm{Ni}^{2+}$. These were two periplasmic subunit family 3 proteins, Dde_0168 (Fig. 8a-b) and Dde_1429 (Fig. 8a) related to export mechanisms and the cell division ATP-binding FtsE protein (Dde_0114) (Fig. 8a-b). ${ }^{29}$

Characterisation of $\mathrm{Co}$ and $\mathrm{Ni}$ nanoparticles High resolution scanning transmission electron microscopy (STEM) was used to confirm that $\mathrm{Co}$ and $\mathrm{Ni}$ NPs were synthesised in the bacterial envelope. To our delight the characterisation revealed zero-valent $\mathrm{Co}$ NPs attached to the cells, the first time to our knowledge that such nanoparticles of this critical metal have been reported. This novel finding was achieved by applying a meticulous examination of the specimens depicted in Fig. 9a. The absence of oxygen in the electron energy loss spectroscopy (EELS) (Fig. 9b) and sulfur in the EDXS (Fig. 9c) spectra rules out the possibility that the NPs are sulfides and/or oxides. The synthesis of biogenic zero-valent Co NPs by the bacterium Geobacter sulfurreducens had been previously speculated but not demonstrated. ${ }^{23}$

The biological mechanisms involved in the formation of zero-valent Co NPs are unknown and deserve further investigation, but have commenced with the proteomics work presented in this study. From these we hypothesise that certain proteins, including the quinoneinteracting membrane-bound oxidoreductase (Dde_1113), are involved in the reduction of $\mathrm{Co}^{2+}$ to $\mathrm{Co}^{0}$ and that other metal-binding affinity proteins in the membrane (Dde_0155, Dde_2208, Dde_3518) may play a role in the nucleation of Co resulting in nanoparticle formation. In addition to zero-valent Co NPs, we identified the formation of nanoparticles made of Co and S (Fig. S6a), and Ni and S (Fig. S6b) on the surface of the bacterial envelope by elemental mapping (EDXS). Precipitation of $\mathrm{Co}$ and $\mathrm{Ni}$ as nanocrystalline metal a
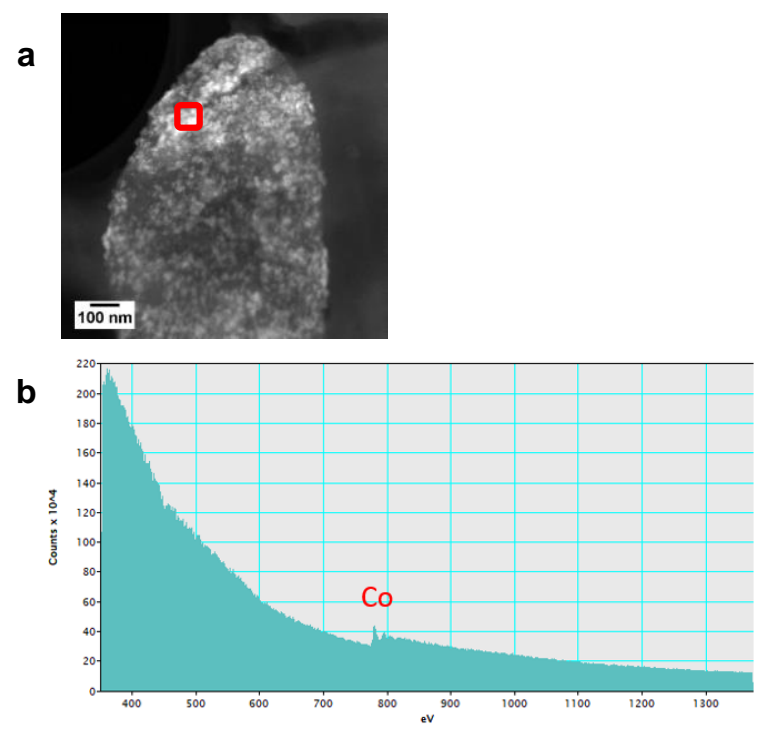

C

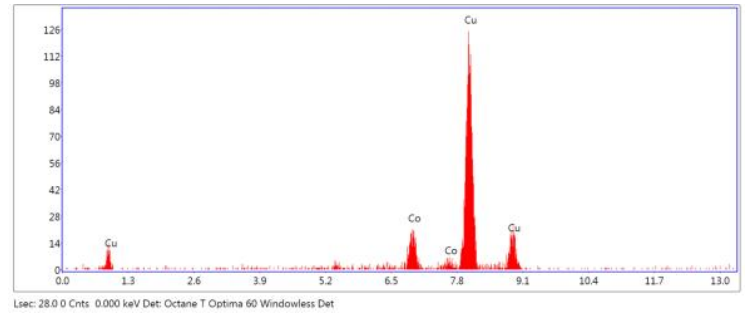

Fig. 9 Characterisation of Co nanoparticles by STEM, EDXS and EELS. (a) STEM image and (b) EELS (c) EDXS spectra taken from the spot highlighted with red square on image a, on surface of $D$. alaskensis $\mathrm{G} 20$ incubated for $20 \mathrm{~h}$ in $\mathrm{Co}^{2+} 10$ $\mathrm{ppm}$, and re-suspended at a final concentration of ethanol $50 \% \mathrm{v} / \mathrm{v}$. Cu peaks in the EDXS are associated to the TEM grid.
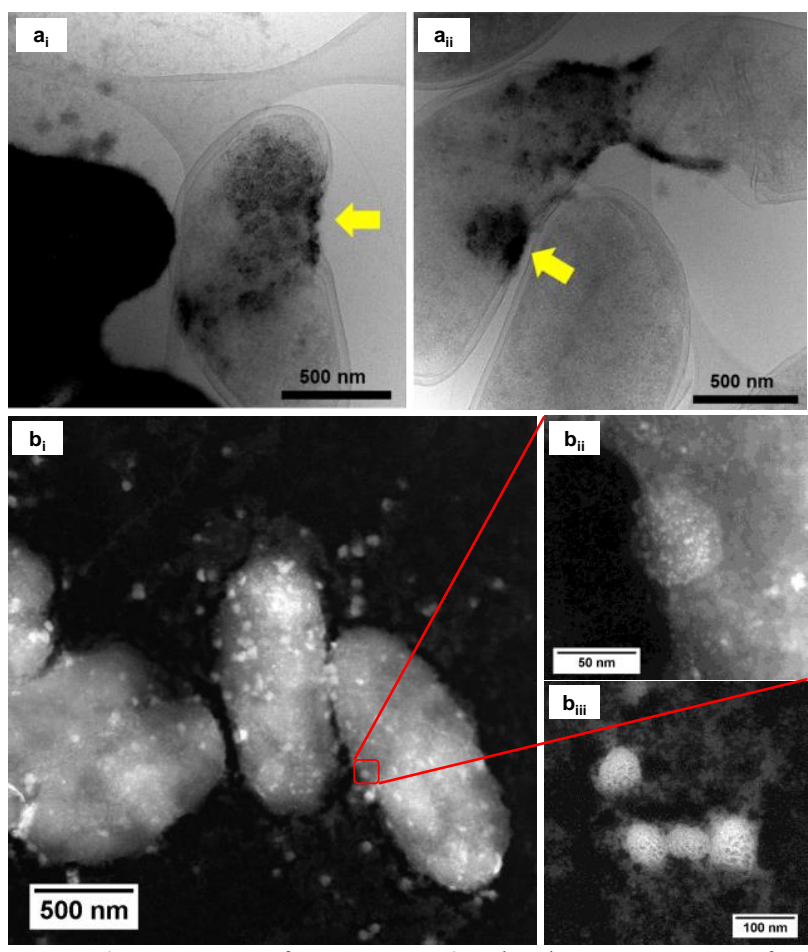

Fig. 10 Characterisation of Co nanoparticles. $\left(a_{\mathrm{i}}-\mathrm{a}_{\mathrm{ii}}\right)$ Cryo-EM images of $D$. alaskensis $\mathrm{G} 20$ incubated for $20 \mathrm{~h}$ in $\mathrm{Co}^{2+} 50$ ppm, yellow arrows point at highdensity areas in the bacterial envelope where Co-based nanoparticles were formed. $\left(\mathbf{b}_{\mathrm{i}}-\mathbf{b}_{\mathrm{iii}}\right)$ STEM image of mesoporous nanostructures synthesised on the bacterial envelope of $D$. alaskensis $\mathrm{G} 20$ cells incubated for $20 \mathrm{~h}$ in $\mathrm{Co}^{2+} 50 \mathrm{ppm}$. 

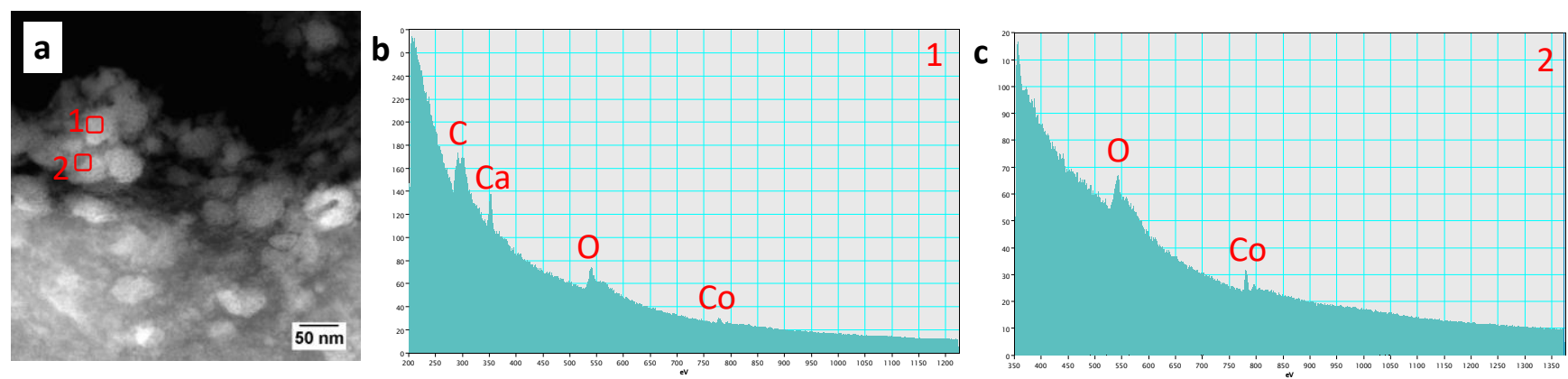

Fig. 11 Characterisation of the mesoporous nanostructures using (a) STEM and (b-c) EELS spectra obtained from regions (a) 1 and 2 highlighted with red squares.

sulfides by the activity of sulfate reducing bacteria (SRB) has been reported previously and is attributed to the presence of biogenic hydrogen sulfide. ${ }^{31}$ In this study the production of dissolved $\mathrm{H}_{2} \mathrm{~S}$ explained the formation of metal nanoparticles containing sulfur, possibly metal sulfides. However, the presence of sulfur in the nanoparticles could also be due to the presence of cysteinyl ligands in relevant proteins binding iron-sulfur clusters. Some proteins binding 4Fe-4S were significantly more abundant after incubation with $\mathrm{Ni}^{2+}$ (Dde_0718, Dde_2176, Dde_1830, Dde_2943). There is a possibility that the iron sites within these metalloproteins have been replaced by $\mathrm{Ni}^{2+}$ and/or $\mathrm{Co}^{2+}$, as observed in rubredoxins-related studies, ${ }^{32}$ and thus end up serving as an anchor and metal nucleation site for the nanoparticles synthesised as observed on the bacterial outer membrane. ${ }^{33}$ To identify the exact location of nanoparticle synthesis we used cryo-EM. The images obtained indicate that Co nanoparticles are synthesised in the bacterial envelope eventually compromising the integrity of the membrane (Fig. 10a $\mathrm{a}_{-} \mathrm{a}_{\mathrm{ii}}$ ). The bacterial envelope under the STEM presented different degrees of degradation depending on the fixative used, ethanol $50 \% \mathrm{v} / \mathrm{v}$ was less aggressive than acetone $50 \% \mathrm{v} / \mathrm{v}$. The images obtained from samples of $D$. alaskensis $\mathrm{G} 20$ incubated with Co salts and fixed with acetone showed mesoporous nanostructures of a diameter $\sim 50 \mathrm{~nm}$ (Fig. 10bFig. 11a). EELS analysis confirmed the presence of $\mathrm{Co}$ in these mesoporous nanoparticles. The increased concentration of metalbinding proteins during incubation with $\mathrm{Co}$ in different locations of the bacterial envelope such as Dde_2670 in the inner membrane and others, such as Dde_0155, Dde_2208, Dde_1113, Dde_3518, in the periplasm support the hypothesis that these Co-based nanostructures are formed due to biological processes. We could not confirm the oxidation state of $\mathrm{Co}$ in this instance because elemental edges associated to $\mathrm{C}, \mathrm{Ca}$ and $\mathrm{O}$ were also present in the EELS spectra (Fig. 11b-c). The presence of Ca could be attributed to accumulation as a result of the direct electron transfer from cytochromes and hydrogenases ${ }^{34}$ or alternatively may be associated to the degraded bacterial envelope surrounding the NPs. ${ }^{35}$

\section{Conclusion}

The need for more efficient and greener methods for recycling metals contained in LIBs is driving research to consider the application of less conventional methodologies. For decades microorganisms have been used extensively in the areas of metal bioremediation ${ }^{36}$ and bioleaching ${ }^{37}$ however their uses for metal bio-separation are still in the early stages. Our work with two different bacterial strains shows the potential for the separation and recovery of all the relevant metals contained in LIBs. First $S$. oneidensis MR-1 precipitates dissolved $\mathrm{Mn}$ followed by the use of $D$. alaskensis $\mathrm{G} 20$ for the recovery of $\mathrm{Co}$ and/or $\mathrm{Ni}$, leaving $\mathrm{Li}$ in the downstream leachate that can be precipitated using chemical methods. ${ }^{8}$ The results presented here show the principles for establishing a bio-based technology and define the areas of research needed for enhancing removal yields and improving metal selectivity. To date there is a wide range of synthetic biology tools available for manipulation of $S$. oneidensis MR-1 that could be applied for improving the removal efficiency of $\mathrm{Mn}^{2+} .{ }^{38}$ The removal of $\mathrm{Co}$ and $\mathrm{Ni}$ was higher with whole cell culture treatment however no selectivity for either metal was observed. In contrast, the utilisation of bacterial cell-only treatment offers greater advantages such as better control of the physicochemical properties of the nanoparticles produced and the potential for enhancing the specificity for Co or Ni by using $D$. alaskensis $\mathrm{G} 20$ engineered strains with their design informed by the proteomics analysis provided herein. ${ }^{39}$ Biological approaches are ideally suited for implementation alongside existing technologies and could form part of battery recycling processes to provide a sustainable incentive for industry and as a solution to fit EV LIB technology within a circular economy. Another exciting finding achieved in this work was the synthesis of novel nanoparticles. The identification of biogenic zero-valent Co NPs shows the potential of biology for producing unique nanoparticles with perhaps novel physicochemical properties. This finding provides us with new insight into the nanoparticle synthesis pathways of $D$. alaskensis $\mathrm{G} 20$ and deserves further investigation.

\section{Experimental}

\section{Bacterial cultures preparation}

S. oneidensis MR-1 was cultured aerobically in Luria Bertani (LB) media without $\mathrm{NaCl}, \mathrm{LB}$ no salts (LBNS). ${ }^{40}$ Overnight cultures (5 ml) were used to inoculate larger volumes $(100-200 \mathrm{ml})$ at $200 \mathrm{rpm}$ and $20^{\circ} \mathrm{C}$ until stationary phase $\left(\mathrm{OD}_{600} \sim 6\right)$. Cultures of $D$. alaskensis $\mathrm{G} 20$ were grown in Postgate Media C (PGMC) as described elsewhere ${ }^{11}$, washed with MOPS buffer $(\mathrm{pH} \mathrm{7.5,10} \mathrm{mM)} \mathrm{and} \mathrm{re-suspended} \mathrm{in} \mathrm{fresh}$ MOPS buffer $\left(O D_{600}=1\right)$.

\section{Measurement of dissolved $\mathrm{H}_{2} \mathrm{~S}$}

The concentration of $\mathrm{H}_{2} \mathrm{~S}$ was measured in fully grown cultures of $D$. alaskensis $\mathrm{G} 20$ and cells resuspended in MOPS in the absence of metal using a $\mathrm{H}_{2} \mathrm{~S}$ microsensor following manufacturer's guidelines (UNISENSE). 


\section{LIB-relevant metal bioremoval}

Stock metal solutions were made in ultrapure water to a concentration of $10 \mathrm{~g} \mathrm{~L}^{-1}$ using Co. $\mathrm{Cl}_{2} \cdot 6 \mathrm{H}_{2} \mathrm{O}, \mathrm{LiCl}, \mathrm{MnSO}_{4} \cdot \mathrm{H}_{2} \mathrm{O}$ and $\mathrm{NiCl}_{2} \cdot 6 \mathrm{H}_{2} \mathrm{O}$ as a source of $\mathrm{Co}^{2+}, \mathrm{Li}^{+}, \mathrm{Mn}^{2+}$ and $\mathrm{Ni}^{2+}$ ions respectively. Bacterial cell cultures and abiotic controls, fresh media and buffers, were incubated with metal solutions in $15 \mathrm{ml}$ falcon tubes at a final volume of $2 \mathrm{ml}$. S. oneidensis MR-1 treatments took place aerobically (20 ${ }^{\circ} \mathrm{C}$ and $200 \mathrm{rpm}$ ), whereas $D$. alaskensis $\mathrm{G} 20$ treatments took place in an anaerobic atmosphere $\left(10 \% \mathrm{CO}_{2}, 10 \% \mathrm{H}_{2}\right.$ in $\mathrm{N}_{2}$ atmosphere, static, $30^{\circ} \mathrm{C}$ ).

Metal removal analysis After a $20 \mathrm{~h}$ incubation $1 \mathrm{ml}$ aliquot samples were collected for metal removal analysis. A volume of $100 \mu$ of this aliquot was acidified with $900 \mu \mathrm{l}$ of $20 \% \mathrm{HNO}_{3}(\mathrm{v} / \mathrm{v})$ to analyse for the total metal concentration. The remaining volume of the sample was centrifuged $\left(2 \mathrm{~h}, 20,000 \mathrm{~g}\right.$ and $4{ }^{\circ} \mathrm{C}$ ), and afterwards $100 \mu \mathrm{l}$ of supernatant (dissolved fraction) was also acidified with $900 \mu$ l of $20 \%$ $\mathrm{HNO}_{3}(\mathrm{v} / \mathrm{v})$. The acidified samples were digested for $5 \mathrm{~h}$ at $80{ }^{\circ} \mathrm{C}$ and diluted afterwards in ultrapure water prior to inductively coupled plasma optical emission spectrometry (ICP-OES) analysis on an Optima 8300 (Perkin Elmer). ${ }^{40}$ Metal removal (\%) from the dissolved fraction was calculated as the difference between the total concentration ( $\mathrm{Tc}$ ) of the metal added and the concentration of metal that remained in the dissolved fraction (Dc) as depicted in the equation (1):

Metal removal $(\%)=((T c-D c) / T c) \times 100$

Differences between $\mathrm{Co}$ and $\mathrm{Ni}$ precipitation across different conditions were analysed with a One Way ANOVA and t-test using SigmaPlot ${ }^{\circledR}$.

\section{Selective bioprecipitation of dissolved $\mathrm{Mn}$ from vehicular LIBs leachates}

The LIB leachates used in the present study were prepared with two different cathode materials. These were commercial cathodes A1C (NM -352)) and B1C (LMO+NCA) obtained from uncycled electric vehicle batteries The cathode materials were dissolved in $\mathrm{H}_{2} \mathrm{SO}_{4}(0.1 \mathrm{M})$ at $50{ }^{\circ} \mathrm{C}$ over a period of 5 to 30 minutes with no agitation. Leachates of $\mathrm{B} 1 \mathrm{C}$ cathode were also produced in $\mathrm{HCl}(0.1 \mathrm{M})$ at $20^{\circ} \mathrm{C}$ for up to $5 \mathrm{~h}$ with no agitation. The bioprecipitation of metals contained in vehicular LIBs leachates was investigated following the same methodology used to investigate metal removal from single-metal solutions. Cultures of $S$. oneidensis MR-1 were incubated with $10 \% \mathrm{v} / \mathrm{v}$ of raw leachates ( $2 \mathrm{ml}$ final volume) prepared in $\mathrm{H}_{2} \mathrm{SO}_{4}(0.1 \mathrm{M}$ ) and $\mathrm{HCl}(0.1 \mathrm{M})$ for $20 \mathrm{~h}$ at $20^{\circ} \mathrm{C}$ and $200 \mathrm{rpm}$. The concentration of metals in the total and dissolved fractions was analysed by ICPOES.

\section{Two bacterial-treatment bio-processing approach}

The different stages of the bio-process approach are summarised graphically in Fig.6 showing the two-bacterial treatments and the resulting fractions involved. The first treatment (T1) consisted of processing the raw leachate mixed with $S$. oneidensis MR-1 to precipitate mainly Mn (T1B). Afterwards the fraction containing the remaining dissolved metals (T1C) was further processed with D. alaskensis G20 (treatment $2, \mathrm{~T} 2$ ) to precipitate $\mathrm{Ni}$ and/or Co. The study was developed with leachates prepared with $\mathrm{A} 1 \mathrm{C}$ and $\mathrm{B} 1 \mathrm{C}$ cathode material delaminated with $\mathrm{H}_{2} \mathrm{SO}_{4}\left(0.5 \mathrm{M}, 20 \mathrm{~min}\right.$ at $\left.50{ }^{\circ} \mathrm{C}\right)$. Carbonate-bicarbonate buffer (final concentration $91 \mathrm{mM}$ ) was added to the $S$. oneidensis MR-1 cell suspension just before the addition of the acidic leachate $(10 \% \mathrm{v} / \mathrm{v})$. Once treated with $S$. oneidensis MR-1 the precipitated metals (T1B) were separated from the metals in the dissolved fraction (T1C) by centrifugation (10 min at 4,500 rpm). Fraction T1C was filter-sterilised $(\varnothing<0.2$ $\mu \mathrm{m}$ ) before incubation with $D$. alaskensis $\mathrm{G} 20$ cells (cell-only treatment, $\mathrm{OD}_{600}=2$, resuspended in MOPS buffer, $\mathrm{pH}$ 7.5) for $20 \mathrm{~h}$ at different concentrations of the pretreated leachate (T1C), by volume, $25 \%$ and $50 \%$, labelled as T2A. The metal removal using whole the cell culture of $D$. alaskensis $\mathrm{G} 20$ (cells and extracellular matrix) was investigated with $50 \% \mathrm{v} / \mathrm{v}$ of leachate. Removal of dissolved metal was calculated as the difference between the total concentration of metal and the remaining concentration in the supernatant after centrifugation as described previously (equation (1)) using ICP-OES.

\section{Proteomics analysis}

Proteomics analysis was designed based on the removal rates of Co and $\mathrm{Ni}$ and considered the following factors: 1 ) three different metal combinations, single metal treatments (only $\mathrm{Co}^{2+}$ or $\mathrm{Ni}^{2+}$ ) and bimetallic $\left(\mathrm{Co}^{2+}\right.$ and $\mathrm{Ni}^{2+}$ at equal concentrations) to mimic the removal experiments; 2 ) two different metal concentration levels (10 and $100 \mathrm{ppm}$ ) and 3) two different time points ( 2 and $20 \mathrm{~h}$ ) to investigate the dynamics of proteins production.

D. alaskensis $\mathrm{G} 20$ cultures for proteomic analysis were grown and washed in MOPS buffer similarly to the metal removal studies and previous proteomics analysis with this organism. ${ }^{29}$ After 2 and $20 \mathrm{~h}$ incubation cell cultures were collected by centrifugation, the supernatants discarded and cell pellets stored at $-75{ }^{\circ} \mathrm{C}$ until proteomic analysis.

ESI-HPLC-MS/MS analysis Samples were reconstituted in $8 \mathrm{M}$ urea and protein concentration was determined by Bradford protein assay (Biorad). 30 $\mu$ g of samples were digested using S-Trap ${ }^{\mathrm{TM}}$ (ProtifFi) following manufacturers protocol. After speed-vacuum drying, peptide samples were re-suspended in MS-loading buffer $(0.05 \% \mathrm{v} / \mathrm{v}$ trifluoroacetic acid in water) to $1 \mu \mathrm{g} \mu \mathrm{l}^{-1}$ final concentration and then filtered using Millex filter before HPLC-MS analysis. $5 \mu \mathrm{l}$ of a 1 to 1 dilution (in $0.05 \%$ TFA) was injected for analysis. Nano-ESI-HPLCMS/MS analysis was performed using an online system, the nanoHPLC (Dionex Ultimate 3000 RSLC, Thermo-Fisher) coupled to a QExactive mass spectrometer (Thermo-Fisher) with a $300 \mu \mathrm{m} \times 5 \mathrm{~mm}$ pre-column (Acclaim Pepmap, $5 \mu \mathrm{m}$ particle size) joined with a $75 \mu \mathrm{m}$ $x 50 \mathrm{~cm}$ column (EASY-Spray, $3 \mu \mathrm{m}$ particle size). The nano-pump was run using solvent $A$ ( $2 \%$ Acetonitrile in water $0.1 \%$ formic acid) and solvent B ( $80 \%$ acetonitrile, $20 \%$ water and $0.1 \%$ formic acid) and peptides were separated using a multi-step gradient of $2-98 \%$ buffer $B$ at a flow rate of $300 \mathrm{nl} \mathrm{min}{ }^{-1}$ over 90 minutes.

Data process and analysis Progenesis (version 4 Nonlinear Dynamics, UK) was used for LC-MS label-free quantitation and data normalisation and analysis. Filtering was carried out so that only MS/MS peaks with positive charges of 2, 3 or 4 were taken into account for the total number of 'features' (signal at one particular retention time and $\mathrm{m} / \mathrm{z}$ ) and only the five most intense spectra per 'feature' were included. MS/MS spectra was searched using MASCOT 
Version 2.4 (Matrix Science Ltd, UK) against a custom D. alaskensis G20 database with maximum missed-cut value set to 2 as in previous proteomics work with this organism. ${ }^{29}$ For convention the protein identifier (protein ID) used in the present work has been given the name of its encoding gene which starts with letters "Dde_" followed by four numeric digits. The updates related to genes and protein annotations can be found at the KEGG database (https://www.genome.jp/kegg/). From the Progenesis exported results sheet, differentially expressed proteins were considered significant if the $p$-value was less than 0.05 (ANOVA) and if the number of peptides used in quantitation per protein was equal to or more than 2. Heat maps were created using $\mathrm{R}$ (https://cran.rproject.org/) after log10 transformation of the normalised abundance data sets.

\section{Nanoparticle characterisation}

X-Ray Powder Diffraction Samples of S. oneidensis MR-1 incubated with $\mathrm{Mn}^{2+}$ were collected by centrifugation at $20^{\circ} \mathrm{C}$ and $4,500 \mathrm{rpm}$ for $10 \mathrm{~min}$. Pellets containing bacterial biomass and bioprecipitated $\mathrm{Mn}$ were washed consecutively with ultrapure water, $70 \% \mathrm{v} / \mathrm{v}$ ethanol and then ultrapure water to remove any remaining dissolved forms of $\mathrm{Mn}$ and to inactivate the bacterial cells. Washed pellets were then freeze-dried, ground in a pestle and mortar and mounted in a silicon deepwell mount prior to XRPD analysis. XRPD data was collected using a Bruker D2 Phaser X-ray powder diffractometer, configured in reflection geometry, using $\mathrm{Cu}$ K $\alpha$ radiation (1.541 $⿱$ ) and a LynXEYE X-ray detector. Data was collected over the two theta range $5-60^{\circ}$ for 15 minutes.

STEM, EDXS and EELS Aliquots of bacterial cultures were collected after $20 \mathrm{~h}$ incubation with metal salts, and resuspended with ethanol or acetone (the final concentration of solvent was $50 \% \mathrm{v} / \mathrm{v}$ ) to inactivate bacterial processes. Afterwards samples were stored and preserved at $4{ }^{\circ} \mathrm{C}$ in an anaerobic atmosphere until characterisation. Nanoparticle production was investigated by using high-resolution aberration-corrected STEM, to resolve their density and their shapes, and EDXS and EELS were used to investigate their elemental distributions. Samples for TEM were dispersed for 10 minutes in an ultrasonic water bath and then small drops of nanoparticle solution were taken on to the carbon coated copper grid. $\mathrm{Ni}$ and $\mathrm{Co}$ nanoparticle characterisation was carried out on these thin films using the aberration-corrected JEOL JEM-2100F at 200kV. ADF-STEM images were obtained using a JEOL annular field detector with a fineimaging probe and a current of $50 \mathrm{pA}$ with a convergence semiangle of $\sim 25 \mathrm{mrad}$ and an ADF detector inner angle of $50 \mathrm{mrad}$. EELS was recorded using a Gatan GIF Quantum SE (model 963). Measurements were performed at a total energy resolution of $\sim 3 \mathrm{eV}$, determined by measuring the full width at half-maximum (fwhm) of the zero-loss peak. The following conditions were chosen for the EELS spectra acquisition: convergence semi-angle $30 \mathrm{mrad}$, collection semi-angle $100 \mathrm{mrad}$, exposure time $0.05 \mathrm{~s}$, dispersions of 0.5 and $1 \mathrm{eV} / \mathrm{ch}$, and probe size $<0.5 \mathrm{~nm}$. EDXS was recorded using EDAX Octane T Optima system, with a windowless $60 \mathrm{~mm}^{2}$ SDD EDX detector.

Cryo-EM Cryosamples were prepared immediately after incubation with and without metal salts using a Vitrobot Mark IV (Thermo Fisher Scientific). Teflon sheets were used between the blotting pads and blotting paper to reduce contamination of the pads. $4 \mu \mathrm{l}$ of sample was applied to freshly glow discharged lacey carbon grids (300 mesh copper grids, C269/C TAAB), blotted and plunged automatically into liquid ethane. Freezing conditions were set to: blotting force -1 , blotting time $2 \mathrm{~s}$, drain time $1 \mathrm{~s}$ and $5 \mathrm{~s}$ wait time with conditions in the sample preparation chamber set to $100 \%$ humidity and room temperature. Samples were stored under liquid nitrogen until imaging. Cryo-EM was performed using a Tecnai F20 200kV electron microscope (Thermo Fisher Scientific). Samples were loaded into the EM using a cryoholder model 626 (Gatan). Imaging was carried out under low dose conditions, with a defocus value of $-5 \mu \mathrm{m}$. Images were acquired using a CMOS F816 camera (TVIPS), using 8kb2 settings.

\section{Author Contributions}

L.E.H conceived and directed the project, V.E.B. planned and conducted experimental work, with support from G.M. H.A. and N.D.B. were responsible for STEM, EDXS and EELS analysis. Automotive LIB leachates were supplied by J.H. X-ray powder diffraction analysis was undertaken by C.K. and CryoEM by M.W.T. All authors contributed to discussions and manuscript writing.

\section{Conflicts of interest}

There are no conflicts to declare.

\section{Acknowledgements}

We would like to thank Lisa Imrie and the EdinOmics facility for proteomics data and analysis, to Steve Mitchell at the Biology Scanning EM Facility (BioSem) for his help with the TEM (Wellcome Trust Multi User Equipment Grant (WT104915MA)) and to Dr. Lorna Eades for her support with the ICP-OES, (School of Chemistry, University of Edinburgh). Shewanella oneidensis MR-1 was generously provided by Prof. Jeff Gralnick at Minnesota University.

This research was supported by the Faraday Institution (grant codes FIRG005 and FIRG027) and EPSRC Fellowship (EP/N026519/1). CryoEM data was acquired in the cryoEM facility in School of Biological Sciences at the University of Edinburgh, which was set up with funding from the Wellcome Trust $(087658 / \mathrm{Z} / 08 / \mathrm{Z})$ and SULSA. MWT is supported by Wellcome Centre for Cell Biology (203149).

\section{References}

1 G. Santos, Transp. Policy, 2017, 59, 71-74.

2 N. Rietmann and T. Lieven, J. Clean. Prod., 2019, 206, 6675.

3 E. Fan, L. Li, Z. Wang, J. Lin, Y. Huang, Y. Yao, R. Chen and F. Wu, Chem. Rev., 2020, 120, 7020-7063.

$4 \quad$ M. Weil, S. Ziemann and J. Peters, The Issue of Metal Resources in Li-Ion Batteries for Electric Vehicles, Springer International Publishing, Cham, 2018.

5 B. K. Sovacool, S. H. Ali, M. Bazilian, B. Radley, B. Nemery, J. Okatz and D. Mulvaney, Science ., 2020, 367, 30-33.

6 T. Or, S. W. D. Gourley, K. Kaliyappan, A. Yu and Z. Chen, 
Carbon Energy, 2020, 2, 6-43.

G. Harper, R. Sommerville, E. Kendrick, L. Driscoll, P. Slater, R. Stolkin, A. Walton, P. Christensen, O. Heidrich, S. Lambert, A. Abbott, K. Ryder, L. Gaines and P. Anderson, Nature, 2019, 575, 75-86.

O. Velázquez-Martínez, J. Valio, A. Santasalo-Aarnio, M. Reuter and R. Serna-Guerrero, Batteries, 2019, 5, 68. Y. Choi and S. Y. Lee, Nat. Rev. Chem., 2020, 4, 638-656. M. H. Wright, S. M. Farooqui, A. R. White and A. C. Greene, Appl. Environ. Microbiol., 2016, 82, 5402-5409. Biotechnol., 2015, 32, 727-731.

Heidrich, Nat. Sustain., 2021, 4, 71-79.

L. Xiao, S. Wang, Y. Wang, W. Meng, B. Deng, D. Qu, Z. Xie and J. Liu, ACS Appl. Mater. Interfaces, 2016, 8, 2536925378.
C. P. Kempes, P. M. van Bodegom, D. Wolpert, E. Libby, J. Amend and T. Hoehler, Front. Microbiol., 2017, 8, 31. G. Calvert, A. H. Kaksonen, K. Y. Cheng, J. Van Yken, B. Chang and N. J. Boxall, Minerals, 2019, 9, 563.

D. L. Thompson, J. M. Hartley, S. M. Lambert, M. Shiref, G. D. J. Harper, E. Kendrick, P. Anderson, K. S. Ryder, L. Gaines and A. P. Abbott, Green Chem., 2020, 22, 7585-7603.

J. Marshall, D. Gastol, R. Sommerville, B. Middleton, V. Goodship and E. Kendrick, Metals., 2020, 10, 773.

C. Lei, I. Aldous, J. M. Hartley, D. L. Thompson, S. Scott, R. Hanson, P. A. Anderson, E. Kendrick, R. Sommerville, K. S. Ryder and A. P. Abbott, Green Chem., 2021, 23, 47104715.

Y. Liu, A. Serrano, V. Wyman, E. Marcellin, G. Southam, J. Vaughan and D. Villa-Gomez, J. Hazard. Mater., 2021, 402, 123506.

L. J. Hauser, M. L. Land, S. D. Brown, F. Larimer, K. L. Keller, B. J. Rapp-Giles, M. N. Price, M. Lin, D. C. Bruce, J. C. Detter, R. Tapia, C. S. Han, L. A. Goodwin, J.-F. Cheng, S. Pitluck, A. Copeland, S. Lucas, M. Nolan, A. L. Lapidus, A. V Palumbo and J. D. Wall, J. Bacteriol., 2011, 193, 42684269.

H. Dulay, M. Tabares, K. Kashefi and G. Reguera, Front. Microbiol., 2020, 11, 2992.

W. M. B. L. Vallee, Met. Part C Spectrosc. Phys. Methods Probing Met. Ion Environ. Met. Met., 1993, 226, 52-71. B. Bennett, in Metals in Biology. Biological Magnetic Resonance, vol 29., eds. G. Hanson and L. Berliner, Springer New York, New York, NY, 2010, pp. 345-370.

T. Schmidt and H. G. Schlegel, J. Bacteriol., 1994, 176, 7045-7054.

A. E. Otwell, R. W. Sherwood, S. Zhang, O. D. Nelson, Z. Li, H. Lin, S. J. Callister and R. E. Richardson, Environ. Microbiol., 2015, 17, 1977-1990.

M. Arenas-Salinas, J. I. Vargas-Pérez, W. Morales, C. Pinto, P. Muñoz-Díaz, F. A. Cornejo, B. Pugin, J. M. Sandoval, W.

A. Díaz-Vásquez, C. Muñoz-Villagrán, F. Rodríguez-Rojas, E.

H. Morales, C. C. Vásquez and F. A. Arenas, Front. Microbiol., 2016, 7, 1160.

M. J. Capeness, L. Imrie, L. F. Mühlbauer, T. Le Bihan and L. E. Horsfall, Microbiology, 2019, 165, 1282-1294.

J. Y. Lee, J. G. Yang, D. Zhitnitsky, O. Lewinson and D. C. Rees, Science ., 2014, 343, 1133-1136.

\section{J. Sitte, K. Pollok, F. Langenhorst and K. Küsel,} Geomicrobiol. J., 2013, 30, 36-47.

I. Moura, M. Teixeira, J. J. G. Moura and J. LeGall, J. Inorg. Biochem., 1991, 44, 127-139.

C. H. Luo, V. Shanmugam and C. S. Yeh, NPG Asia Mater., 2015, 7, e209.

F. Goulhen, A. Gloter, F. Guyot and M. Bruschi, Appl. Microbiol. Biotechnol., 2006, 71, 892-897.

C. F. Chang, H. Shuman and A. P. Somlyo, J. Bacteriol., 1986, 167, 935-939.

M. Valls and V. De Lorenzo, FEMS Microbiol. Rev., 2002, 26, 327-338.

J. J. Roy, B. Cao and S. Madhavi, Chemosphere, 2021, 282, 130944.

B. E. Logan, R. Rossi, A. Ragab and P. E. Saikaly, Nat. Rev. Microbiol., 2019, 17, 307-319.

M. J. Capeness and L. E. Horsfall, Biochem. Soc. Trans., 2020, 48, 1367-1378.

M. J. Capeness, V. Echavarri-Bravo and L. E. Horsfall, Front. Microbiol., 2019, 10, 997. 